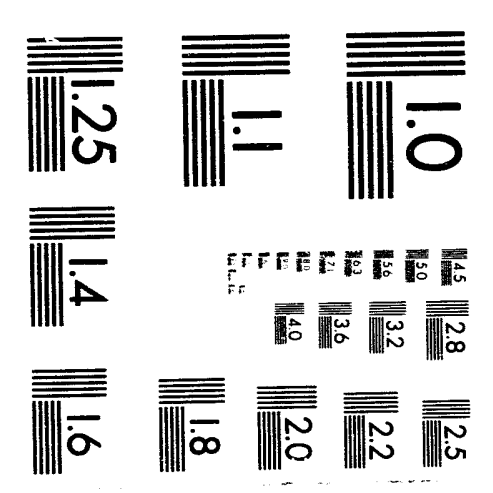



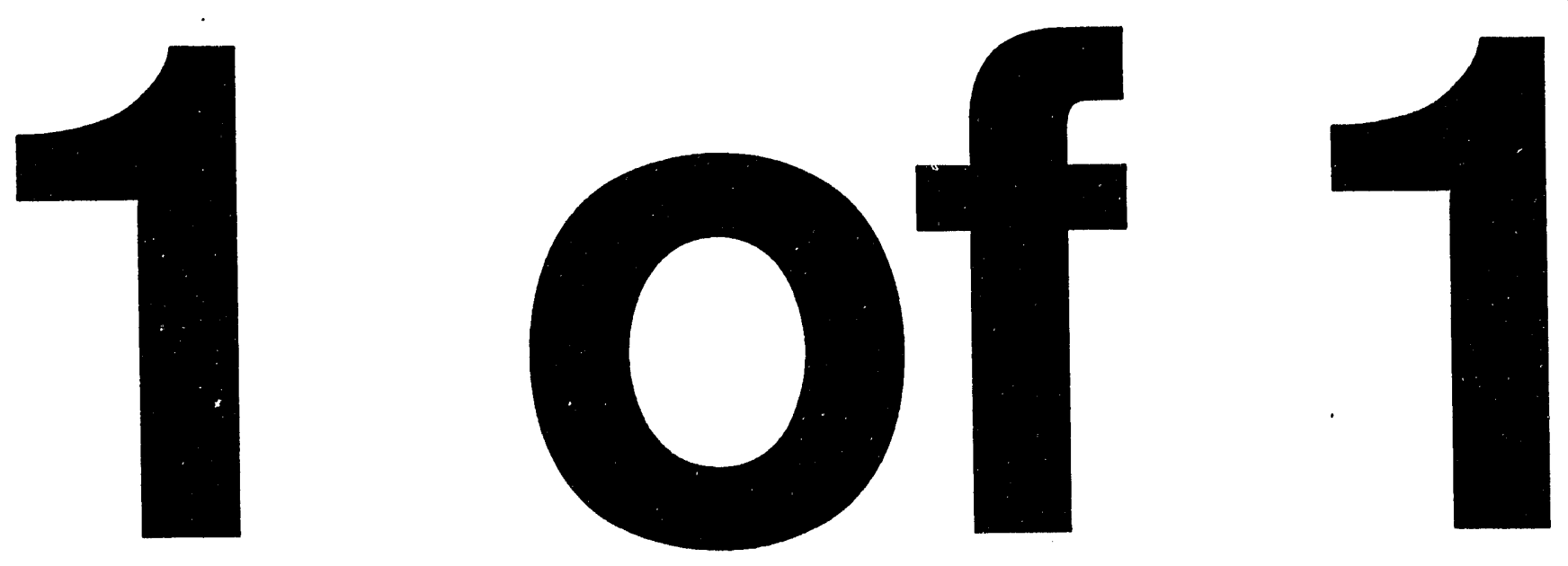


\title{
TOXICITY EVALUATION AND HAZARD REVIEW for RIGID FOAM
}

\author{
Melecita M. Archuleta \\ and \\ William E. Stocum \\ Industrial Hygiene and Toxicology \\ Sandia National Laboratories \\ Albuquerque, NM 87185
}

\begin{abstract}
Rigid Foam is a chemical delay foam used to completely encapsulate an object or to block access to an area. Prior studies have indicated that the final foam product is essentially non-toxic. The purpose of this study was to evaluate and summarize the current chemical and toxicological data available on the components of Rigid Foam and to update the information available on the toxicity of the final Rigid Foam product. Since the possibility exists for a partial deployment of Rigid Foam where only one of the components is released, this study also examined the toxicity of its chemical constituents. Rigid Foam is composed of an " $\mathrm{A}$ " and " $\mathrm{B}$ " Component. The " $\mathrm{A}$ " component is primarily a polymeric isocyanate and the "B" component is a mixture of polyols. In addition to the primary constituents, dichlorodifluoromethane and trichlorofluoromethane are present as blowing agents along with catalysts and silicone surfactants necessary for foaming. The predeployed "A" and "B" components are stored in separate vess and are brought together in static mixing nozzles for dispersal. The results of this evaluation indicate that a completely deployed Rigid Foam under normal conditions is essentially non-toxic as determined previously. However, in the event of a partial deployment or deployment of an individual conponent directly at an unprotected individual, the degree of hazard is increased due to the toxic and corrosive nature of the individual constituents. The health hazard would depend on the properties of the material to which the person was exposed.


Toxicology Evaluation and Hazard Review

Rigid Foam

\section{Contents}

Nomenclature ................................................................................. 5

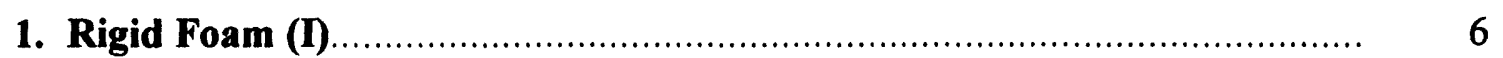

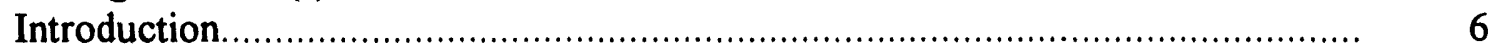

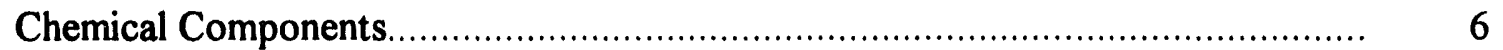

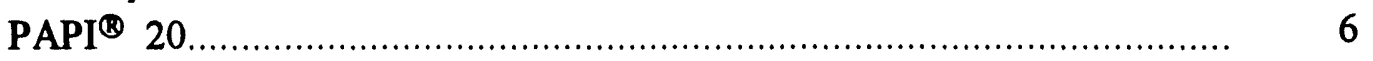

Dow Corning ${ }^{\circledR}$ DC 193 .............................................................. 9

Pluracol $^{\circledR}$ Polyol 480................................................................. 12

Pluracol ${ }^{\circledR}$ Polyol 434.............................................................. 14

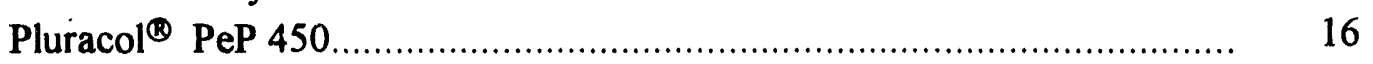

Tetramethylethylene diamine......................................................... 18

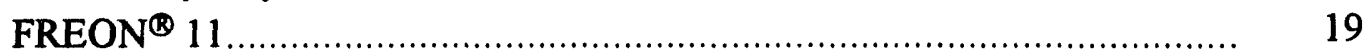

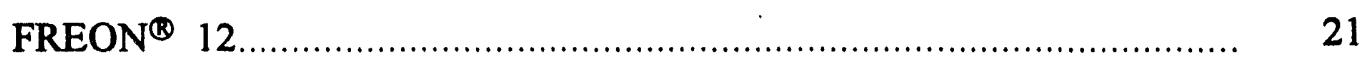

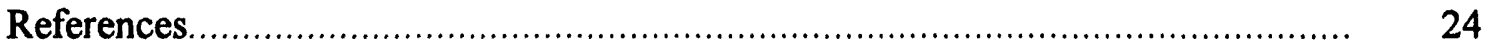

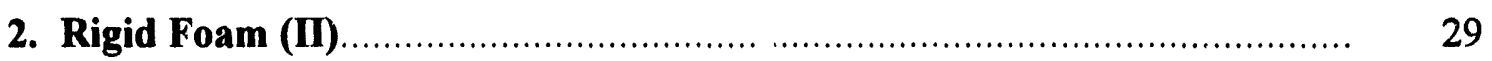

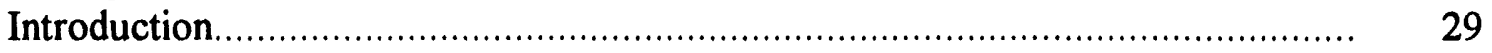

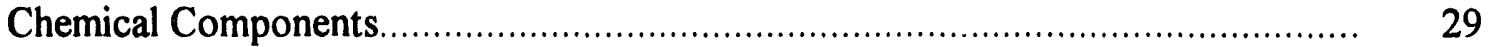

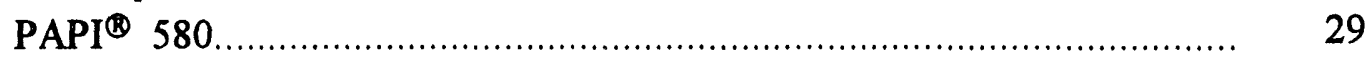

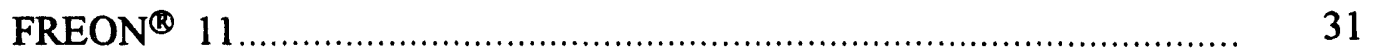

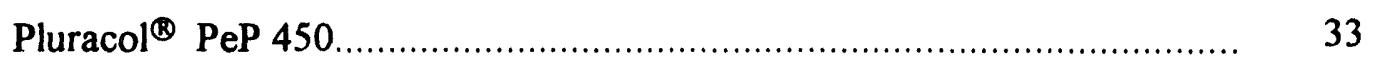

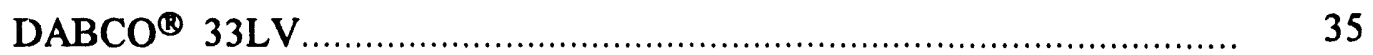

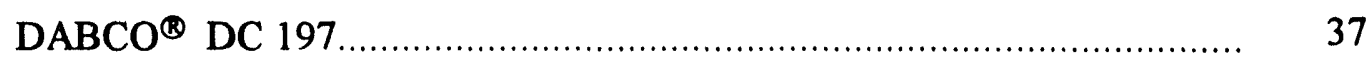

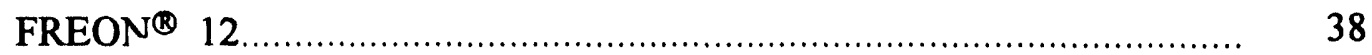

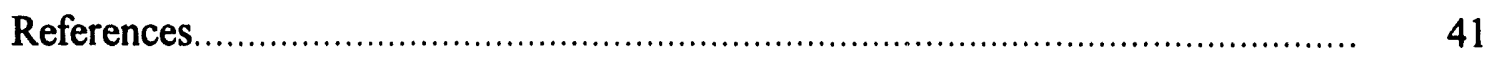

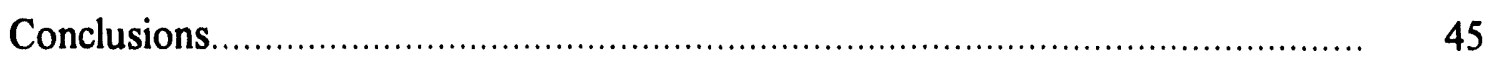




\section{Nomenclature}

ACGIH

ASTM

BEI

CEIL

$\mathrm{COC}$

CNS

HSDB

IARC

LC50

LD50

NA

$\mathrm{NCI}$

NCITR

NIOSH

NTP

OSHA

PEL

PM

REL

RTECS

SBR

STEL

TC

TLV

TWA

$\begin{array}{ll}\mathrm{g} & \text { grams } \\ \mathrm{hr} & \text { hours } \\ \mathrm{kg} & \text { kilograms } \\ \mathrm{m}^{3} & \text { cubic meters } \\ \mathrm{min} . & \text { minutes } \\ \mathrm{mg} & \text { milligrams } \\ \mathrm{ml} & \text { millimeters } \\ \mathrm{ppm} & \text { parts per million }\end{array}$
studied.

parts per million
American Conference of Governmental Industrial Hygienists

American Society for Testing and Materials

biological exposure indices

ceiling, The concentration that should not be exceeded during any part of the working exposure.

Cleveland Open Cup

central nervous system

Hazardous Substances Data Bank

International Agency for the Research of Cancer

Lethal concentration - fifty $=$ Concentration that leads to death in $50 \%$ of the population studied (used in inhalation studies).

Lethal dose fifty $=$ Dose that leads to death in $50 \%$ of the population

Information not available

National Cancer Institute

National Cancer Institute Toxicity Report

National Institute of Occupational Safety and Health

National Toxicology Program

Occupational Safety and Health Administration

permissible exposure limit

Pensky-Martens Closed Cup

recommended exposure limit

Registry of Toxic Effects of Chemical Substances

Styrene Butadiene Rubber

short term exposure limit

toxic concentration

threshold limit value

time weighted average ( 8 hour) 


\section{TOXICOLOGY EVALUATION AND HAZARD REVIEW \\ for RIGID FOAM}

\section{RIGID FOAM (Formulation I)}

\section{Introduction}

Rigid Foam (Formulation I) is composed of two components that are mixed together on deployment to form the final foam product. Component " $A$ " is prepared with a polymeric isocyanate, $\left(\mathrm{PAPI}^{\circledR}\right)$; a propylene oxide adduct of phosphoric acid, (Pluracol ${ }^{\circledR} 480$ ); and a silicone block copolymer (DABCO ${ }^{\circledR}$ DC193). The "B" component of Rigid Foam (I) is composed of a mixture of propylene oxide adducts (Pluracol ${ }^{\circledR} 434$, Pluracol ${ }^{\circledR} 480$, and Pluracol $^{\otimes}$ PeP 450) dissolved in trichlorofluoromethane (FREON $\left.{ }^{\otimes}-11\right)$. A tertiary amine catalyst (tetramethylethylene diamine), and a silicone block copolymer (DABCO ${ }^{\otimes}$ DC193) is also added to the "B" component of Rigid Foam (I). Prior to placement in the predeployment vessels, each of the above components are blended with FREON ${ }^{\circledR}-12$. Components " $\mathrm{A}$ " and "B" are brought together in static mixing nozzles for dispersal (1). The A:B mix ratio is $1: 1$ by volume. Due to the differences in the $A: B$ weight ratios for vessel filling and for static mixing, the more toxic " $A$ " component should finish dispensing before the " $B$ " component rendering an essentially non-toxic foam product (2). This report summarizes the current chemical and toxicological literature on the individual constituents of Rigid Foam (I) and discusses the health hazards associated with various exposure scenarios. Chemical and physical properties and exposure limits are also given when available $(3,4)$.

\section{PAPI $^{\circledR 20}$}

\section{Chemical Name $(5,6)$ :}

polymethylene polyphenyl isocyanate

\section{Molecular Formula:}

$\left(\mathrm{C}_{15} \mathrm{H}_{10} \mathrm{~N}_{2} \mathrm{O}_{2}\right)_{\mathbf{X}}$

$50 \%$ methylene bisphenylisocyanate (MDI) and 50\% MDI polymers 


\section{CAS Number:}

9016-87-9

\section{Chemical and Physical Properties (5,6):}

Melting Point: NA

Boiling point: $392^{\circ} \mathrm{F}\left(200^{\circ} \mathrm{C}\right)$

Flash Point: $425^{\circ} \mathrm{F}\left(218^{\circ} \mathrm{C}\right)$, COC

Appearance: Dark amber viscous liquid

Odor: Threshold (Vapor) $=0.4 \mathrm{ppm}$

Solubility in Water: reacts

Log Octanol/water partition coefficient: NA

\section{Exposure limits (7):}

(as methylene bisphenylisocyanate):

OSHA PEL: $\quad$ CEIL $=0.2 \mathrm{mg} / \mathrm{m}^{3}(0.02 \mathrm{ppm})$

NIOSH REL: TWA $=0.05 \mathrm{mg} / \mathrm{m}^{3}(0.005 \mathrm{ppm})$

$\begin{array}{ll}\text { ACGIH TLV: } & \text { TWA } 10 \mathrm{~min} . \text { CEIL }=0.051 \mathrm{mg} / \mathrm{m}^{3}\left(0.005 \mathrm{mp} / \mathrm{m}^{3}\right. \\ \text { TWm }\end{array}$

Toxicology : Polymethylene polyphenyl isocyanate may be harmful by inhalation, ingestion, or skin absorption. Vapor mist is irritating to the eyes, mucous membranes and upper respiratory tract. Isocyanates are very reactive substances that are also capable of reacting with proteins to form antigens resulting in a severe allergic respiratory reactions (8). In summary, it is expected that at concentrations between 0 and $0.02 \mathrm{ppm}$ there is little danger of any allergic reaction to the isocyanate. At levels greater than $0.02 \mathrm{ppm}$ but less than $0.1 \mathrm{ppm}$, a small percentage of the general population may exhibit symptoms of sensitivity. At concentrations of 0.1 to $1 \mathrm{ppm}$, initation of the respiratory tract and mucous membranes will occur and at concentration of $1.0 \mathrm{ppm}$ and greater there is a potential of acute toxic effects.

Oral-rat LD50 $=>10,000 \mathrm{mg} / \mathrm{kg}(9)$.

Skin-rabbit LD50 $=>5 \mathrm{ml} / \mathrm{kg}(9)$.

Acute Exposure: Acute exposure to polyisocyanates results in irritation of the eyes, mucous membranes and upper respiratory tract. Polyisocyanates may cause respiratory tract irritation, chest discomfort, breathlessness, wheezing, cough with sputum, and reduced pulmonary function $(9,10)$.

Chronic Exposure: Clinical studies have indicated that a small percentage of the population (17\%) become sensitized when exposed to isocyanates. Subsequent exposure of these sensitized individuals can lead to an asthmatic-like reaction and severe respiratory distress $(9,11)$. 
Eye Exposure: Isocyanate vapors are highly irritating to the mucous membranes of the eyes, nose, throat, and lungs. Exposure of the eyes to liquid isocyanates may result in dehydration of the tissue causing severe irritation of the eyelid and possible damage to the cornea. Exposure to high concentrations of isocyanate vapor can lead to formation of solid crystals in the eye fluid causing mechanical irritation of the eyes hours after exposure $(3,9,12)$.

Inhalation Exposure: Inhalation of isocyanate vapors can produce severe irritation of the mucous membranes in the respiratory tract, i.e., nose, throat, and lungs (13). Exposure of humans to concentrations of isocyanate vapor in excess of the maximum acceptable concentration $\left(0.2 \mathrm{mg} / \mathrm{m}^{3} \mathrm{CEIL}\right)$ has caused illness characterized by breathlessness, chest discomfort, and reduced pulmonary function. Furthermore, isocyanate exposure has caused, within minutes, irritation of the trachea and larynx and severe coughing spasms leading to bronchitis, bronchial spasm, and/or pulmonary edema (chemical pneumonitis) which can be fatal (14). Isocyanate exposure in individuals with existing respiratory disease, i.e., chronic bronchitis, emphysema, bronchiectasis, previous histoplasmosis, tuberculosis, or sarcoidosis, is likely to cause aggravation (9).

Oral Exposure: Animal experiments indicate that the toxic effects of polymeric isocyanates, when ingested, are slight. The LD50 in rats for PAPI ${ }^{\circledast}$ is greater than $10,000 \mathrm{mg} / \mathrm{kg}$ (9). Therefore, although it is believed that ingestion of polymeric isocyanates are not expected to be fatal to humans, ingestion can result in irritation and corrosive action on the mouth and stomach tissue (15).

Dermal Exposure: Exposure of the skin to PAPI ${ }^{\circledR}$ does not result in toxic effects other than irritation and potential sensitization. Prolonged or repeated contact with polymeric isocyanates or contact with highly sensitive or allergic personnel however, can result in chemical burns, dermatitis and sensitization. The dermal LD50 after continuous 24 hour contact with the shaved skin of male, albino rabbit is greater than $5 \mathrm{ml} / \mathrm{kg}(9,16)$.

Carcinogenicity: There is insufficient evidence that MDI is mutagenic in the Ames assay. Furthermore, there is currently no evidence that PAPI ${ }^{\circledR}$ produces carcinogenic effects in humans or animals. PAPI ${ }^{\circledR}$ is not listed as a carcinogen by NTP, IARC, or ACGIH nor is it regulated as a carcinogen by $\operatorname{OSHA}(7,9)$. However, free methylenedianiline, a known carcinogen, has been found in thermally degraded MDI based polyurethane foams (17).

Reproductive Effects: There is currently no data implicating isocyanates in toxic reproductive or teratogenic effects $(3,4)$.

Incompatibility: Polymethylene polyphenyl isocyanate is incompatible with strong oxidizing agents, acids, bases, some metals, and alcohols. Polymeric isocyanates also react slowly and exothermically on contact with water $(5,6)$. 
Hazardous Decomposition Products: Toxic fumes of carbon monoxide, carbon dioxide, nitrogen oxides, and hydrogen cyanides, may be produced upon thermal decomposition of isocyanates (18). Thermal decomposition of PAPI ${ }^{\circledR}$ foams at temperatures that do not result in ignition have been known to produce toxic isocyanate vapors and methylenedianiline (MDA) a known carcinogen $(17,19)$.

\section{Dow Corning ${ }^{\circledR}$ DC 193}

Chemical Name (20):

Dimethylpolysiloxane (polyoxyethyleneglycol) silicone copolymer

\section{Molecular Formula:}

NA

CAS Number:

68937-54-2

Chemical and Physical Properties (21):

Melting Point: NA

Boiling point: $>300^{\circ} \mathrm{F}\left(>149^{\circ} \mathrm{C}\right)$

Flash Point: $198^{\circ} \mathrm{F}$, TCC

Appearance: Clear Liquid

Odor: None

Solubility in Water: $>50 \%$

Octanol/water partition coefficient: No data

Exposure limits (7):

No occupational exposure limits have been established by ACGIH, OSHA or NIOSH.

Toxicology : Silicone oils such as DC 193 are characterized by their chemical inertness, low temperature coefficient of viscosity, wide liquid range and low freezing point. Silicone oils and silicone polymers have a low order of toxicity as a group, but repeated contact to dimethylpolysiloxane (polyoxyethyleneglycol) silicone copolymer can result in mild skin and eye irritation (21).

Oral-rat LD50 $=>64 \mathrm{gm} / \mathrm{kg}(22)$.

Skin-rabbit LD50 = > $16 \mathrm{gm} / \mathrm{kg}(22)$.

Acute Exposure: Acute inhalation or dermal exposure to dimethyl polysiloxanes causes mild irritation and discomfort (2). Acute over exposure to the products of combustion may result in irritation of the respiratory tract. 
Chronic Exposure: Repeated or prolonged exposure to the skin may cause primary skin irritation and dermatitis. DC193 has been shown to enhance allergic conditions such as skin allergies $(20,21)$. There is no indication that silicones produce the chronic health effects seen with chronic exposure to silica dust (23).

Eye Exposure: Direct contact with the eyes may cause temporary discomfort with mild redness and dryness similar to windburn $(3,12)$.

Inhalation Exposure: Although chronic inhalation exposure to respirable silica dust results in a chronic fibrosing lung disease (silicosis), there is no evidence of adverse health effects resulting from inhalation exposure to silicon oxide polymers (silicones) such as the silicone copolymer in DC $193(23,24,25)$.

Oral Exposure: Silicones in general, have a very low oral toxicity. There is no evidence of adverse health effects due to ingestion of polydimethylsiloxane other than gastrointestinal irritations (22).

Dermal Exposure: A single relatively short exposure (5 - 10 minutes) causes no known adverse effects. However, several repeated prolonged exposures ( 24 to 48 hours) may irritate the skin resulting in dermatitis $(21,22)$.

Carcinogenicity: Studies of women with silicone implants have not demonstrated a causal relationship between silicone implants, cancer or autoimmune disease (23, 24, 25). Dimethylpolysiloxane (polyoxyethyleneglycol) Silicone Copolymer is not listed as a carcinogen by NTP, IARC, or ACGIH, nor is it regulated as a carcinogen by OSHA(7).

Reproductive Effects: Studies on the reproductive and teratogenic effects of dimethylpolysiloxanes have been inconclusive $(26,27)$. However epidemiological studies on women with silicone implants have demonstrated an increase in reproductive or teratogenic effects due to silicone (24).

Incompatibility: This material is not compatible with strong oxidizing compounds (20, 21).

Hazardous Decomposition Products: Thermal decomposition of this material may produce toxic fumes of silicon dioxide, carbon dioxide, and traces of incompletely burned carbon products $(19,20)$. 
Chemical Name (28):

Ethoxylated Alcohols, (makes up $12 \%$ of Dow Corning ${ }^{(1)}$ DC193 Surfactant).

\section{Molecular Formula:}

C11-C15

\section{CAS Number:}

27274-31-3

68131-40-8

\section{Chemical and Physical Properties (28):}

Melting Point: $102^{\circ} \mathrm{F}\left(39^{\circ} \mathrm{C}\right)$

Boiling point: $>482^{\circ} \mathrm{F}\left(>250^{\circ} \mathrm{C}\right)$

Flash Point: ${ }^{\circ} \mathrm{F}, \mathrm{COC}$

Appearance: White waxy solid

Odor: Mild odor

Solubility in Water: $100 \%$

Log Octanol/water partition coefficient: NA

\section{Exposure limits (7):}

No occupational exposure limits have been established by ACGIH, OSHA or NIOSH.

Toxicology : Ethoxylated alcohols are considered mild skin and eye irritants.

Skin-rabbit LD50 $=4 \mathrm{~g} / \mathrm{kg}$ (3).

Oral-rat LD50 $=8570 \mathrm{mg} / \mathrm{kg}$ (3).

Acute Exposure: Ethoxylated alcohols are considered to have moderate toxicity via dermal absorption and inhalation (28).

Chronic Exposure: Repeated or prolonged dermal or inhalation exposure to ethoxylated alcohols results in enhancement of acute effects (28).

Eye Exposure: Acute eye exposure to ethoxylated alcohols may cause moderate to severe irritation with possible corneal injury. There is no data available on the effects of chronic eye exposure (12).

Inhalation Exposure: Due to its low vapor pressure, ethoxylated alcohols pose no significant health hazard from inhalation exposure at normal room temperatures. Inhalation of generated mists or vapors produced at elevated temperatures may cause irritation of the mucous membranes. There is currently no data available on chronic inhalation exposure to ethoxylated alcohols $(3,4)$.

Oral Exposure: Ingestion of ethoxylated alcohols may cause nausea $(3,4)$. 
Dermal Exposure: Direct co.tact of ethoxylated alcohols to the skin may cause irritation and redness. Repeated or prolonged exposure to ethoxylated alcohols can result in absorption of potentially lethal amounts $(28,29)$.

Carcinogenicity: Ethoxylated alcohols are not listed as carcinogens by NTP, IRAC, or ACGIH, nor are they regulated as carcinogens by OSHA (7).

Reproductive Effects: There are no known reproductive effects associated with ethoxylated alcohols $(3,4)$.

Incompatibility: Ethoxylated alcohols are incompatible with strong acids and bases and form a fire and explosion hazard with strong oxidizers (28).

Hazardous Decomposition Products: Thermal decomposition products may include toxic oxides of carbon (28).

\section{Pluracol $^{\circledR}$ Polyol 480}

Chemical Name (30):

propylene oxide adduct of phosphoric acid, 440 hydroxyl number.

Molecular Formula:

NA

CAS Number:

NA

Chemical and Physical Properties (30):

Melting Point: NA

Boiling point: Not distillable

Flash Point: $>200^{\circ} \mathrm{F}, \mathrm{COC}$

Appearance: Water white oily liquid

Odor: No odor

Solubility in Water: Insoluble

\section{Exposure limits (7):}

No occupational exposure limits have been established by ACGIH, OSHA, or NIOSH.

Toxicology : The toxicological effects of this material have not been evaluated. The following information on potential health effects is based on the toxicological information available for similar materials such as polypropylene glycol. In 
general, polypropylene glycols pose essentially no toxicity hazard following dermal or inhalation exposure (31). A probable oral lethal dose in humans is estimated to be above $15 \mathrm{~g} / \mathrm{kg}(32)$.

Acute Exposure: Acute ingestion is not expected to result in toxicity (32). Contact with the eyes and skin may result in irritation. There are no other known acute effects associated with exposure to Pluracol $^{\circledR} 480(33$,$) .$

Chronic Exposure: There are no known effects associated with chronic exposure to polypropylene glycols $(3,4,33)$.

Eye Exposure: Direct contact of the liquid with the eyes may result slight transient pain and conjunctiva irritation but no corneal damage $(12,33)$.

Inhalation Exposure: Due to its low vapor pressure, Pluracol ${ }^{\circledR 80}$ is not considered an inhalation hazard at normal temperatures. Monkeys and rats exposed to atmuspheres saturated with propylene glycol vapor experienced no adverse effects after periods of 12 - 18 months. Furthermore, humans exposed to saturated and supersaturated atmospheres for prolonged periods did not exhibit serious toxicological effects $(33,34)$.

Oral Exposure: Oral exposure is not considered a major route of exposure in the workplace. However, glycols are generally well absorbed by the digestive tract resulting in moderate toxicity following chronic ingestion (32).

Dermal Exposure: The primary route of exposure expected with this material is dermal. Tests on rabbits have indicated that polypropylene glycols are not significantly irritating to the skin even when exposures are prolonged and repeated (33).

Carcinogenicity: None of the glycols or their derivatives have found to be mutagenic, carcinogenic, or teratogenic. This Pluracol ${ }^{\circledR} 480$ has not been listed as a carcinogen by NTP, IARC, or ACGIH nor is it regulated as carcinogens by OSHA (7).

Reproductive Effects: There are no known reproductive effects associated with Pluracol ${ }^{\circledR} 480(3,4)$. Although some glycol ethers such as ethylene glycol monomethyl ether and ethylene glycol monoethyl ether have been associated with reproductive toxicity, propylene glycols are not considered reproductive toxins $(35,36)$.

Incompatibility: There are no known incompatible materials that affect the health hazards of this material. Reaction with moisture however will degrade the material (30). 
Hazardous Decomposition Products: Thermal decomposition results in the formation of carbon monoxide and carbon dioxide (30).

\section{Pluracol $^{\circledR}$ Polyol 43,4}

Chemical Name (37):

Propylene oxide adduct of 80/20 2, 4-(2,6-toluene diamine hydroxyl \# 380) $(26.8 \%)$.

\section{Molecular Formula:}

Polyether Poiyol

CAS Number:

NA

Chemical and Physical Properties (37):

Melting Point: NA

Boiling point: Not distillable

Flash Point: $>200^{\circ} \mathrm{F}, \mathrm{COC}$

Appearance: Dark brown, viscous liquid

Odor: No odor

Solubility in Water: Insoluble

\section{Exposure limits (7):}

No occupational exposure limits have been established by ACGIH, OSHA, or NIOSH..

Toxicology : The toxicological effects of this material have not been extensively evaluated. Pluracol 434 may cause slight skin or eye irritation on contact. Oral-rat LD50 $=1843 \mathrm{mg} / \mathrm{kg}^{\mathrm{a}}$ (37).

Dermal-rabbit LD50 $=>2025 \mathrm{mg} / \mathrm{kg}^{\mathrm{a}}$ (37)

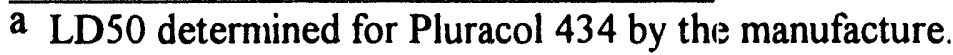

The following information on potential health effects for Pluracol 434 is based the information available for this material and on the toxicological information available for similar materials such as polypropylene glycol. In general, polypropylene glycols pose essentially no toxicity hazard following dermal or inhalation exposure (31). 
Acute Exposure: Acute ingestion is not expected to result in toxicity (32). Contact with the eyes and skin may result in irritation. There are no other known acute effects associated with exposure to Pluracol $^{\circledR} 434(8,33)$.

Chronic Exposure: There are no known effects associated with chronic exposure to polypropylene glycols $(3,4,33)$.

Eye Exposure: Direct contact of the liquid with the eyes may result slight transient pain and conjunctiva irritation but no corneal damage $(12,37)$.

Inhalation Exposure: Due to its low vapor pressure, Pluracol ${ }^{\circledR} 434$ is not considered an inhalation hazard at normal temperatures. Monkeys and rats exposed to atmospheres saturated with propylene glycol vapor experienced no adverse effects after periods of 12 - 18 months. Furthermore, humans exposed to saturated and supersaturated atmospheres for prolonged periods did not exhibit serious toxicological effects $(33,34)$.

Oral Exposure: Oral exposure is not considered a major route of exposure in the workplace. However, glycols are generally well absorbed by the digestive tract resulting in moderate toxicity following chronic ingestion (32).

Dermal Exposure: The primary route of exposure expected with this material is dermal. Tests on rabbits have indicated that polypropylene glycols are not significantly irritating to the skin even when exposures are prolonged and repeated (33).

Carcinogenicity: None of the glycols or their derivatives have found to be mutagenic, carcinogenic, or teratogenic. Pluracol ${ }^{\circledR} 434$ has not been listed as a carcinogen by NTP, IARC, or ACGIH nor is it regulated as carcinogens by OSHA (7).

Reproductive Effects: There are no known reproductive effects associated with Pluracol ${ }^{\circledR} 434(3,4)$. Although some glycol ethers such as ethylene glycol monomethyl ether and ethylene glycol monoethyl ether have been associated with reproductive toxicity, propylene glycols are not considered reproductive toxins $(35,36)$.

Incompatibility: There are no known incompatible materials that affect the health hazards of this material. However, the MSDS for this material suggests avoidance of exposures to moisture and temperatures above $200^{\circ} \mathrm{F}(37)$.

Hazardous Decomposition Products: Thermal decomposition results in the formation of carbon monoxide and carbon dioxide (37). 


\section{Pluracol $^{\oplus}$ PeP 450:}

Chemical Name (38):

Propylene oxide adduct of penetaerythritol, 560 hydroxyl number (28.1\%).

Molecular Formula:

Polyether Polyol

CAS Number:

9051-49-4

Chemical and Physical Properties (38, 39):

Melting Point: NA

Boiling point: Nố distillable

Flash Point: $365^{\circ} \mathrm{F}, \mathrm{COC}$

Appearance: Water white, viscous liquid

Odor: No odor

Solubility in Water: Soluble

\section{Exposure limits (7):}

No occupational exposure limits have been established by ACGIH, OSHA, or NIOSH.

Toxicology : The toxic effects of this material have not been determined. Pluracol 434 may cause slight skin or eye irritation upon contact. Acute toxicity studies in the rat suggest that this material is essentially non-toxic with a Rat-oral LD50 $=20.8$ $\mathrm{g} / \mathrm{kg}$ (38).

The following information on potential health effects for Pluracol 434 is based the information available for this material and on the toxicological information available for similar materials such as polypropylene glycol. In general, polypropylene glycols pose essentially no toxicity hazard following dermal or inhalation exposure (31).

Acute Exposure: Acute ingestion is not expected to result in toxicity (32). Contact with the eyes and skin may result in irritation. There are no other known acute effects associated with exposure to Pluracol$^{\circledR} 450(8,33)$.

Chronic Exposure: There are no known effects associated with chronic exposure to polypropylene glycols $(3,4,33)$.

Eye Exposure: Direct contact of the liquid with the eyes may result slight transient pain and conjunctiva irritation but no corneal damage $(12,38)$. 
Inhalation Exposure: Due to its low vapor pressure, PEP 450 poses no inhalation hazard at normal temperatures. Monkeys and rats exposed to atmospheres saturated with propylene glycol vapor experienced no adverse effects after periods of 12 - 18 months. Furthermore, humans exposed to saturated and supersaturated atmospheres for prolonged periods did not exhibit serious toxicological effects $(33,34)$.

Oral Exposure: Oral exposure is not considered a major route of exposure in the workplace. However, glycols are generally well absorbed by the digestive tract resulting in moderate toxicity following chronic ingestion (32).

Dermal Exposure: The primary route of exposure expected with this material is dermal. Tests on rabbits have indicated that polypropylene glycols are not significantly irritating to the skin even when exposures are prolonged and repeated (33).

Carcinogenicity: None of the glycols or their derivatives have found to be mutagenic, carcinogenic, or teratogenic. Pluracol ${ }^{\$ 4} 450$ has not been listed as a carcinogen by NTP, IARC, or ACGIH nor is it regulated as carcinogens by OSHA (7).

Reproductive Effects: There are no known reproductive effects associated with Pluracol ${ }^{\circledR} 450(3,4)$. Although some glycol ethers such as ethylene glycol monomethyl ether and ethylene glycol monoethyl ether have been associated with reproductive toxicity, propylene glycols are not considered reproductive toxins $(35,36)$.

Incompatibility: There are no known incompatible materials that affect the health hazards of Pluracol ${ }^{\circledR} 450$. However, the MSDS for this material suggests avoidance of exposures to moisture and temperatures above $200^{\circ} \mathrm{F}(38,39)$.

Hazardous Decomposition Products: No hazardous decomposition products have been identified. This material does not undergo hazardous polymerization $(38,39)$. 


\section{Tetramethylethylenediamine}

Chemical Name (40):

Tetramethylethylenediamine

Molecular Formula:

$\left(\mathrm{CH}_{3}\right)_{2} \mathrm{~N}-\mathrm{CH}_{2} \mathrm{CH}_{2}-\mathrm{N}\left(\mathrm{CH}_{3}\right)_{2}$

CAS Number:

110-18-9

Chemical and Physical Properties (41):

Melting Point: $-67^{\circ} \mathrm{F}\left(-55^{\circ} \mathrm{C}\right)$

Boiling point: $248-252^{\circ} \mathrm{F}\left(120-122^{\circ} \mathrm{C}\right)$

Flash Point: $50^{\circ} \mathrm{F}, \mathrm{COC}$

Appearance: Yellow liquid

Odor: Ammonia odor

Solubility in Water: soluble

Log Octanol/water partition coefficient: NA

\section{Exposure limits (7):}

No occupational exposure limits have been established by ACGIH, OSHA, or NIOSH.

Toxicology : Tetramethylethylene diamine is considered harmful if swallowed, inhaled, or absorbed through the skin. This material is caustic and is extremely destructive to the tissues of the mucous membranes and upper respiratory tract, eyes and skin (2, $3,41,42)$.

Oral-rat LD50 $=1580 \mathrm{mg} / \mathrm{kg}(3)$.

Skin-rabbit LD50 $=5390 \mathrm{mg} / \mathrm{kg}(43)$.

Acute Exposure: Acute exposure to tetramethylethylene diamine results in severe irritation and damage to tissues of the mucous membranes and upper respiratory tract, eyes and skin $(3,4)$.

Chronic Exposure: There is no information available on the effects of chronic exposure to this material. However, based on its irritating potential, chronic dermal exposure may result in moderate to severe dermatitis $(3,4)$.

Eye Exposure: Severe eye irritation was seen in the eyes of rabbits exposed to $750 \mu \mathrm{g}$ of tetramethylethylene diamine $(12,44)$. 
Inhalation Exposure: Inhalation of this material may be fatal as a result of spasm, inflammation and edema of the larynx and bronchi, chemical pneumonitis and pulmonary edema $(40,41)$.

Oral Exposure: Due to its caustic properties, ingestion of tetramethylethylene diamine can result in burns and inflammation of the mouth and throat $(42,43)$.

Dermal Exposure: Prolonged skin contact can cause severe irritation or burns $(41,42)$.

Carcinogenicity: Mutagenicity studies with tetramethylethylene diamine at concentrations of 100 to $10,000 \mu$ /plate indicate that this material is not mutagenic in the Ames assay (45). This material is not listed as a carcinogen by NTP, IARC, or ACGIH, nor is it regulated as a carcinogen by OSHA (7).

Reproductive Effects: There are no known reproductive or teratogenic effects associated with this material $(3,4)$.

Incompatibility: Tetramethylethylene diamine is incompatible with acids, acid chlorides, acid anhydrides, strong oxidizing agents and carbon dioxide $(38,39)$.

Hazardous Decomposition Products: Thermal decomposition may produce carbon monoxide, carbon dioxide, and nitrogen oxides $(38,39)$.

\section{FREON ${ }^{\circledR} 11$}

Chemical Name (46):

Trichlorofluoromethane

Molecular Formula:

$\mathrm{CCl}_{3} \mathrm{~F}$

CAS Number:

75-69-4

Chemical and Physical Properties (46):

Melting Point: $-168^{\circ} \mathrm{F}\left(-111^{\circ} \mathrm{C}\right)$

Boiling point: $75^{\circ} \mathrm{F}\left(24^{\circ} \mathrm{C}\right)$

Flash Point: None TOC

Appearance: Colorless liquid

Odor: Slight ethereal odor 
Solubility in Water: $0.1 \%$ by wt. @ $77^{\circ} \mathrm{F}$

Exposure limits (7):

OSHA PEL: $\quad$ CEIL $=5620 \mathrm{mg} / \mathrm{m}^{3}(1000 \mathrm{ppm})$

NIOSH: $\quad$ CEIL $=5600 \mathrm{mg} / \mathrm{m}^{3}(1000 \mathrm{ppm})$

ACGIH TLV: CEIL $=5600 \mathrm{mg} / \mathrm{m}^{3}(1000 \mathrm{ppm})$

Toxicology : Trichlorofluoromethane $\left(\right.$ FREON $\left.^{\circledR} 11\right)$ is a colorless gas or liquid used as a refrigerant and/or propellant (46). It is toxic following inhalation of the vapors or prolonged skin exposure. In screening tests with experimental animals, exposure to approximately $5,000 \mathrm{ppm}(\mathrm{v} / \mathrm{v})$ and followed by an intravenous epinephrine challenge has induced serious cardiac irregularities $(3,4)$.

Rat - Oral LD50 = >3725 mg/kg (46).

Rat - Inhalation LC50 $=26,200 \mathrm{ppm} / 4 \mathrm{hr}$. (46).

Acute Exposure: Vapor is heavier than air and can cause suffocation by reducing oxygen available for breathing. Concentrations of 10,000 ppm are considered immediately dangerous to life or health (3).

Chronic Exposure: Repeated or prolonged dermal exposure to FREON ${ }^{\circledR} 11$ may cause dermatitis with irritation, reddening, drying and cracking of skin (47).

Eye Exposure: Chronic exposure to FREON ${ }^{\circledR} 11$ in the eyes of rabbits resulted in no observable damage other than a mild hyperemia and slight inflammation of the eyelid $(12,48)$. Rapid evaporation of the liquid gas may cause frostbite, pain, and blurred vision.

Inhalation Exposure: FREON ${ }^{\circledR}-11$ is considered a simple asphyxiant / narcotic (3). Exposure to high concentrations of the gas may cause pulmonary edema, bronchial constriction, lung irritation and central nervous system depression. The symptoms of asphyxia depend on the rapidity with which the oxygen deficiency develops and how long it continues. In sudden acute asphyxia, unconsciousness may be immediate. With slow development there may be rapid respiration and pulse, dizziness, reduced awareness, tightness in the head, tingling sensations, incoordination, faulty judgment, emotional instability and rapid fatigue. As the asphyxia progresses, nausea, vomiting, collapse, unconsciousness, convulsions, coma and death are possible (49). In addition acute exposures to high concentration of chlorofluorocarbons has caused sudden death by cardiac arrest, probably due to sensitization of the myocardium to endogenous catecholamines resulting in ventricular fibrillation $(49,50)$.

Oral Exposure: Ingestion of the gas is unlikely, however, ingestion of the liquid can produce frostbite, damage to the lips, mouth and mucous membranes $(3,51)$. 
Dermal Exposure: FREON ${ }^{\circledR} 11$ is not a corrosive or irritant material, however, repeated or prolonged contact with the liquid can cause defatting of the skin resulting in dermatitis. Individuals with pre-existing skin disorders may be more susceptible to the effect of this agent (47).

Carcinogenicity: Exposure of trichlorofluoromethane to sprague-dawley rats did not result in carcinogenic effects (52). FREON ${ }^{\circledR} 11$ is not listed as a carcinogen by NTP, IARC or ACGIH, nor is it regulated as a carcinogen by OSHA (7).

Reproductive Effects: There have been no reproductive effects noted with this compound $(3,4)$.

Incomputibility: FREON ${ }^{\circledR} 11$ is incompatible with alkali or alkaline earth metals powdered $\mathrm{Al}, \mathrm{Zn}$, and $\mathrm{Be}(46)$.

Hazardous Decomposition Products: FREON ${ }^{\circledR} 11$ can be decomposed by high temperatures (open flames, glowing surfaces etc.) forming hydrochloric and hydrofluoric acids and possible carbonyl halides (46).

\section{FREON ® 12}

Chemical Name (53):

Dichlorodifluoromethane

Molecular Formula:

$\mathrm{Cl} 2-\mathrm{C}-\mathrm{F} 2$

CAS Number:

75-71-8

Chemical and Physical Properties (53):

Melting Point: $-252^{\circ} \mathrm{F}\left(-158^{\circ} \mathrm{C}\right)$

Boiling point: $-22^{\circ} \mathrm{F}\left(-30^{\circ} \mathrm{C}\right)$

Flash Point: NA

Appearance: Colorless Gas

Odor: Faint ether-like odor

Solubility in Water: $0.028 \% @ 25^{\circ} \mathrm{C}$

Log Octanol/water partition coefficient: NA 
Exposure limits (7):

OSHA PEL: TWA - $1000 \mathrm{ppm}\left(4950 \mathrm{mg} / \mathrm{m}^{3}\right)$

NIOSH TWA - $1000 \mathrm{ppm}\left(4950 \mathrm{mg} / \mathrm{m}^{3}\right)$

ACGIH TLV: TWA - 1000 ppm $\left(4950 \mathrm{mg} / \mathrm{m}^{3}\right)$

Toxicology: Dichlorodifluoromethane $\left(\right.$ FREON $\left.^{\circledR}-12\right)$ is a colorless gas with a faint odor commonly used as a refrigerant and/or propellant (53). Exposure may effect the central nervous system and respiration. Sudden death has been reported following intentional inhalation of freons. It is believed that the cause of death is due to ventricular fibrillation as a result of direct sensitization of the myocardium to endogenous catecholamines $(50,54)$.

Acute Exposure: Acute exposure to FREON $^{\circledR}-12$ may cause drunkenness, suffocation, blisters, frostbite, blurred vision, nausea, vomiting, twitching, weakness, numbness, convulsions, blood disorders, heart failure, collapse, unconsciousness and coma (49).

Chronic Exposure: Repeated or prolonged exposure to FREON ${ }^{\circledR}-12$ may result in effects similar to a large acute exposure (50).

Eye Exposure: Ordinary occupational and domestic exposure to the fluorocarbons is not expected to cause ocular irritation. Hovever, 200,000 ppm for 30 minutes has been reported to cause irritation (51). Rapid evaporation of the liquefied gas may cause frostbite, redness, pain, and blurred vision (12).

Inhalation Exposure: FREON ${ }^{\star}-12$ is considered a simple asphyxiant / narcotic. Exposure to high concentrations of the gas may cause pulmonary edema, bronchial constriction, lung irritation and central nervous system depression. The symptoms of asphyxia depend on the rapidity with which the oxygen deficiency develops and how long it continues. In sudden acute asphyxia, unconsciousness may be immediate. With slow development there may be rapid respiration and pulse, dizziness, reduced awareness, tightness in the head, tingling sensations, incoordination, faulty judgment, emotional instability and rapid fatigue. As the asphyxia progresses, nausea, vomiting, collapse, unconsciousness, convulsions, coma and death are possible (49). In addition acute exposures to high concentrations of chlorofluorocarbons has caused sudden death by cardiac arrest, probably due to sensitization of the myocardium to endogenous catecholamines resulting in ventricular fibrillation $(49,50)$.

Oral Exposure: Ingestion of the gas is unlikely, however, ingestion of the liquid can produce frostbite, damage to the lips, mouth and mucous membranes $(3,51)$.

Dermal Exposure: No adverse effects have been reported following dermal exposure to the gas. However, rapid evaporation of the liquefied material may cause frostbite with redness, tingling, pain or numbness $(4,53)$. 
Carcinogenicity: FREON ${ }^{\circledR}-12$ is not listed as a carcinogen by NTP, IRAC, or ACGIH, nor is it regulated as a carcinogen by $\operatorname{OSHA}(3,4)$.

Reproductive Effects: There have been no reproductive effects noted with this compound $(3,4)$.

Incompatibility: Under certain conditions, fluorocarbons can form exothermic reactions with aluminum, calcium, magnesium, metals, potassium, sodium, and zinc (53).

Hazardous Decomposition Products: Thermal decomposition products may include toxic fumes of phosgene and carbonyl halides and toxic and corrosive fumes of chlorides and fluorides. Hazardous polymerization has not been reported to occur under normal temperatures and pressures (53). 


\section{References}

1. Rand, P.R., Personal communication. (1993).

2. Stocum, W.E., Unpublished Report. (1986).

3. National Library of Medicine Toxicology Data Network, Hazardous Substance Data Bank (HSDB). TOXNET, (1993).

4. National Library of Medicine Toxicology Data Network, Registry of Toxic Effects of Chemical Substances (RTECS). TOXNET, (1993).

5. DOW Corning Corporation. PAPI - 20. U.S. Department of Labor Occupational Safety and Health Administration, Material Safety Data Sheet, (1987).

6. DOW Corning Corporation PAPI - 27. U.S. Department of Labor Occupational Safety and Health Administration, Material Safety Data Sheet, (1987).

7. American Conference of Governmental Industrial Hygienists, Guide to Occupational Exposure Values-1992. ISBN:0-936?12-98-8, (1992).

8. Amdur, M.O., Doull, J., and Klaassen, C.D., CASarett and Doull's Toxicology, Fourth Edition., Mc Graw-Hill, (1991).

9. Woolrich, P.F., Toxicology, Industrial Hygiene and Medical Control of TDI, MDI, and PMPPI. AIHA J., 43 (2): 89-97, (1982).

10. Clayton, G.D., and Clayton, F.E., Polyurethanes. In Patty's Industrial Hygiene and Toxicology, A Wiley-Interscience Publication 3rd edition, Vol. 2C, p. 4447-4464 (1991).

11. Karol, M.H., Dixon, D., Brady, and Alarie, Y., Immunologic Sensitization and Pulmonary Hypersensitivity by Repeated Inhalation of Aromatic Isocyanates. Toxicol. Appl. Pharmacol., 58: 260-270, (1980).

12. Grant, W.M., Toxicology of the Eye. Third Edition, Charles C. Thomas (1986).

13. Karol, M.H., Concentration-dependent Immunologic Response to Toluene Diisocyanate (TDI) Following Inhalation Exposure. Toxicol. Appl. Pharmacol., 68: 229-241, (1983).

14. The Upjohn Chemical Company, Urethanes, Engineering, Medical Control and Toxicological Considerations, Technical Bulletin-105, (1968). 
15. Brugsch, H.G., and Elkins, H.B., Toluene Di-isocyanate (TDI) Toxicity. New England J. of Med. 268: 353-357, (1963).

16. Karol, M.H., Hauth, B.A., Riley, E.J., and Magreni, C.M., Dermal Contact with Toluene Di-isocyanate (TDI) Produces Respiratory Tract Hypersensitivity in Guinea Pigs. Toxicol. Appl. Pharmacol., 58: 221-230, (1981).

17. Larsen, F., On the Generation of Methylenedianiline from the Thermal Degradation of MDI Based Polyurethane Foams. Allied Signal Aerospace, Kansas City Division, Polymers Technical Exchange Conference Allied-Signal Corporate Headquarters Morristown, New Jersey, (1992).

18. Hileman, F.D., Voorheers, K.J., Wojcik, L.H., et. al. Pyrolysis of a Flexible Urethane Foam. J. Polymer Sci. 13: 571-580, (1975).

19. Foti, S., Maravigna, P., Montando, G., Mechanisms of Thermal Decomposition in Totally Aromatic Polyurethanes, J. Poly-Sci., 19: 1679- , (1981).

20. DOW Corning Corporation, DOW Corning ® 193 Surfactant, U.S. Department of Labor Occupational Safety and Health Administration, Material Safety Data Sheet, (1985).

21. Occupational Health Services, $D A B C O D C 193$. U.S. Department of Labor Occupational Safety and Health Administration, Material Safety Data Sheet, (1993).

22. Carpenter, C.P., Weil, C.S., and Smyth, H.F., Range Finding Toxicity Data Toxicol. Appl. Pharmacol., 28(2): 313-319 (1974).

23. International Agency for Research on Cancer, Silica and Some Silicates. IARC Monographs on the Evaluation of the Carcinogenic Risk of Chemicals To Humans, 42: 39-144, (1987).

24. Nemecek, J.A., and Young, V.L., How Safe are Silicone Breast Implants?, Southern Med. J., 86(8): 933-944, (1993).

25. Hidalgo, D.A., Are Breast Prostheses Safe for Use in Breast Reconstruction? Yes. Important Advances in Oncology, 179-188, (1993).

26. Kennedy, G.L., Keplinger, MiE., Calandra, J.C., Reproductive, Teratologic, and Mutcigenic Studies with Some Polydimethylsiloxanes. J. Toxicol. Environ. Health, 1(6): 909-920, (1976).

27. Bates, H.R., Filler, H.R., Kimmel, C., Developmental Toxicity Study of Polydimethylsiloxane Injection in the Rat. Teratology, 31: 50-58, (1985). 
Toxicology Evaluation and Hazard Review

Rigid Foam

28. Occupational Health Services, Ethoxylated Alcohols. U.S. Department of Labor Occupational Safety and Health Administration, Material Safety Data Sheet, (1993).

29. Parmeggiani, L., Ethylene Oxide, In Encyclopedia of Occupational Health and Safety, p. 797-799, (1983).

30. BASF Wyandotte Corporation, Pluracol Polyol 480, U.S. Department of Labor Occupational Safety and Health Administration, Material Safety Data Sheet, (1980).

31. Parmeggiani, L., Glycols and Derivatives, In Encyclopedia of Occupational Health and Safety, p. 973-976, (1983).

32. Gosselin, R.E., Smith, R.P., and Hodge, H.C., Polypropylene glycols. In Clinical Toxicology of Commercial Products, 5th edition, p. II-179, (1984).

33. Clayton, G.D., and Clayton, F.E., Glycols and Glycol Derivatives. in Patty's Industrial Hygiene and Toxicology. Vol. 2A, 2B, and 2C, 3rd edition, A WileyInterscience Publication, (1991).

34. Landry, T.D., Gushow, T.S., and Yano, B.L., Propylene Glycol Monomethylether: a 13-week Vapor Inhalation Toxicity Study in Rats and Rabbits. Fund. Appl. Toxicol., 3: $627-630,(1983)$.

35. Hanley, T.R., Young, J.T., John, J.A., and Roa, D.L., Ethylene Glycol Monomethyl Ether (EGME) and Propylene Glycol Monomethyl Ether (PGME): Inhalation Fertility and Teratogenicity Studies in Rats, Mice and Rabbits. Environ. Health Prospect., 57: 7-12, (1984).

36. Schenker, M., Epidemiologic Study of Reproductive and Other Health Effects Among Workers Employed in the Manufacture of Semiconductors. Division of Occupational / Environmental Medicine and Epidemiology Department of Internal Medicine, (1992).

37 BASF Wyandotte Corporation, Pluracol Polyol 434, U.S. Department of Labor Occupational Safety and Health Administration, Material Safety Data Sheet, (1980)

38. BASF Wyandotte Corporation, Pluracol Polyol 450, U.S. Department of Labor Occupational Safety and Health Administration, Material Safety Data Sheet, (1980).

39. Occupational Health Services, Pluracol Polyol 450, U.S. Department of Labor Occupational Safety and Health Administration, Material Safety Data Sheet, (1980).

40. Siigma-Aldrich Corporation, Tetramethylethylenediamine (TMED), U.S. Department of Labor Occupational Safety and Health Administration, Material Safety Data Sheet, (1980). 
Toxicology Evaluation and Hazard Review

Rigid Foam

41. Occupational Health Services, Tetramethylethylenediamine (TMED), U.S.

Department of Labor Occupational Safety and Health Administration, Material Safety Data Sheet, (1980).

42. Brieger, H., and Hodes, W.A., The Toxic Effects of Exposure to Vapors of Aliphatic Amines. A.M.A. Archives of Industrial Hygiene and Occupational Medicine, 3: 287 291 (1951).

43. Smyth, H.R., Carpenter, C.P., Weil, C.S., Pozzani, U.C., Striegel, J.A., and Nycum, J.S., Range-Finding Toxicity Data. Am. Ind. Hyg. Assoc. J., 30(5): 470-476 (1969).

44. Bloom, S.M., Gittinger, J.W., and Dazarian, E.L., Management of Corneal Contact thermal Burns. A. J. Ophthalmol. 102(4): 536 (1986).

45. Zeiger, E., Anderson, B., Haworth, S., Lawlor, T., Mortelmans, K., and Speck, W., Salmonella Mutagenicity Tests: Results from the Testing of 255 Chemicals. Environ. Mutagen., 9(9): 1-110. (1987).

46. Occupational Health Services, Trichlorofluoromethane, U.S. Department of Labor Occupational Safety and Health Administration, Material Safety Data Sheet, (1980).

47. Goodman, A.G., and Gilman, A.G., Goodman and Gilman's: The Pharmacological Basis of Terapeutics. 5th edition, p. 910, (1975).

48. World Health Organization, Fully Halogenated Chlorofluorocarbons. Environmental Health Critera 113: p. 93, (1990).

49. Clark, D.G., and Tinston, D.J., Acute Inhalation Toxicity of Some Halogenated and Non-halogenated Hydrocarbons. Human Toxicology 1: 239-247, (1982)

50. Poika, M. J., Heikkila, J., and Saarinen, L., Cardiac Arrhythmias During Occupational Exposure to Fluorinated Hydrocarbons. British Journal of Industrial Medicine, 47: 138-140, (1990).

51. Parmeggiani, L., Fluorocarbons, In Encyclopedia of Occupatiosal hicalth and Safety, p. $896-899$ (1983).

52. Maltoni, C., Lefemine, G., Tovoli, D., and Perino, G., Long-Term Carcinogenicity Bioassays on Three Chlorofluorocarbons, Trichlorofluoromethane FCII, Dichlorodifluoromethane FC12, (hlorodifluoromethane FC22, Administered by Inhalation to Sprague-Dawley Rats and Swiss Mice. Annals. of the New York Academy of Sciences, NY, NY 534: 261-282, (1988). 
Toxicology Evaluation and Hazard Review

Rigid Foam

53. Occupational Health Services Inc., Dichlorodifluoromethane. Material Safety Data Sheet, (1992).

54. Azar, A., Reinhardt, C.F., Maxfield, M.E., Smith, P.E., and Mullin, L.S., Experimental Human Exposures to Fluorocarbon 12 (Dichlorodifluoromethane) Amer. Indust. Hygiene Assoc. J., April: 207-216, (1972). 


\section{RIGID FOAM (Formulation II)}

\section{Introduction}

Formulation Il contains in the blended "A" component, a polymeric isocyanate (PAPI ${ }^{\oplus}$ $580)$ dissolved in trichlorofluoro methane (FREON $\left.{ }^{\circledR}-11\right)$. The blended "B" component contains Pluracol ${ }^{\circledR}$ PeP 450, a polyoxypropylene pentaerythritol polyether polyol; $\mathrm{DABCO}^{\circledR} \mathrm{DC197}$, a silicone block copolymer which replaced the $\mathrm{DC193;} \mathrm{DABCO}^{\circledR}$ $33 \mathrm{LV}$, a tertiary amine catalyst; and FREON ${ }^{\circledR}-12$, dichlorodifluoro methane. Again, components " $\mathrm{A}$ " and " $\mathrm{B}$ " are brought together in static mixing nozzles for dispersal at a $A: B$ mixing ratio that allows for the complete reaction of the toxic " $A$ " component in excess "B" (1). This report summarizes the current chemical and toxicological literature on the specific constituents of Rigid Foam (II) and reports on the health hazards associated with various exposure scenarios. Chemical and physical properties and exposure limits are also given when available $(2,3)$.

\section{PAPI ${ }^{\circledR} \mathbf{5 8 0}$}

Chemical Name (4):

Polymethylene polyphenyl isocyanate

Molecular Formula:

$50 \%$ methylene bisphenylisocyanate (MDI) and $50 \%$ MDI polymers

$\left(\mathrm{C}_{15} \mathrm{H}_{10} \mathrm{~N}_{2} \mathrm{O}_{2}\right)_{\mathrm{x}}$

\section{CAS Number:}

9016-87-9

Chemical and Physical Properties (4, 5):

Melting Point: NA

Boiling point: $625^{\circ} \mathrm{F}\left(329^{\circ} \mathrm{C}\right)$

Flash Point: $425^{\circ} \mathrm{F}\left(218^{\circ} \mathrm{C}\right)$, COC

Appearance: Dark brown liquid

Odor: Threshold (Vapor) $=0.4 \mathrm{ppm}$

Solubility in Water: reacts 


\section{Exposure limits (6)}

(as methylene bisphenylisocyanate):

OSHA PEL: $\quad$ CEIL $=0.2 \mathrm{mg} / \mathrm{m}^{3}(0.02 \mathrm{ppm})$

NIOSH REL: TWA $=0.05 \mathrm{mg} / \mathrm{m}^{3}(0.005 \mathrm{ppm})$

TWA $10 \mathrm{~min}$. CEIL $=0.2 \mathrm{mg} / \mathrm{m}^{3}(0.02 \mathrm{ppm})$

ACGIH TLV: TWA $=0.051 \mathrm{mg} / \mathrm{m}^{3}(0.005 \mathrm{ppm})$

Toxicology :Polymethylenepolyphenyl isocyanate may be harmful by inhalation, ingestion, or skin absorption. Vapor mist is irritating to the eyes, mucous membranes and upper respiratory tract. Isocyanates are very reactive substances capable of reacting with proteins to fonn antigens resulting in a severe allergic respiratory reactions (7).

Oral-rat LD50 $=>10,000 \mathrm{mg} / \mathrm{kg}(8)$.

Skin-rabbit LD50 $=>5 \mathrm{ml} / \mathrm{kg}(8)$.

Acute Exposure: Acute exposure to polyisocyanates results in irritation of the eyes, mucous membranes and upper respiratory tract $(8,9)$. Polyisocyanates may cause respiratory tract irritation, chest discomfort, breathlessness, wheezing, cough with sputum, and reduced pulmonary function (10).

Chronic Exposure: Clinical studies have indicated that a small percentage of the population (17\%) become sensitized when exposed to isocyanates. Subsequent exposure of these sensitized individuals can lead to an asthmatic-like reaction and severe respiratory distress (10).

Eye Exposure: Exposure of the eyes to liquid isocyanates may result in dehydration of the tissue causing severe irritation of the eyelid and possible damage to the cornea. Exposure of high concentrations of isocyanate vapor can lead to formation of solid crystals in the eye fluid causing mechanical irritation of the eyes hours after exposure $(2,11)$.

Inhalation Exposure: Inhalation of isocyanate vapors can produce severe irritation of the mucous membranes in the respiratory tract, i.e., nose, throat, and lungs (12). Exposure of humans to concentrations of isocyanate vapor in excess of the maximum acceptable concentration $\left(0.2 \mathrm{mg} / \mathrm{m}^{3}\right)$ has caused illness characterized by breathlessness, chest discomfort, and reduced pulmonary function. Isocyanate exposure has caused, within minutes, irritation of the trachea and larynx and severe coughing spasms which may lead to bronchitis, bronchial spasm, and/or pulmonary edema (chemical pneumonia) which can be fatal (13) .

Oral Exposure: Animal experiments indicate that the toxic effects of polymeric isocyanates, when ingested, are slight. The LD50 in rats for PAPI is greater than $10,000 \mathrm{mg} / \mathrm{kg}$. Therefore, although it is believed that ingestion of polymeric 
isocyanate would not be fatal to humans, exposure could result in irritation and corrosive action on the mouth and stomach tissue (14).

Dermal Exposure: Exposure of the skin to PAPI ${ }^{\oplus}$ does not result in toxic effects other than irritation and potential sensitization. Prolonged or repeated contact with polymeric isocyanates or contact with highly sensitive or allergic personnel however, can result in chemical burns, dermatitis and sensitization. The dermal LD50 after continuous 24 hour contact with the shaved skin of male, albino rabbit is greater than $5 \mathrm{ml} / \mathrm{kg}(8,15)$.

Carcinogenicity: There is currently no evidence that PAPI ${ }^{\circledR}$ produces carcinogenic or teratogenic effects in humans or animals. PAPI is not listed as a carcinogen by NTP, IARC or ACGIH, nor is it regulated as a carcinogen by OSHA. $(6,8)$. However, thermal degradation of PAPI foam can result in the release of methylenedianiline (MDA) a known carcinogen (16).

Incompatibility: Isocyanates are found to be incompatible with strong oxidizing agents, bases and alcohols. Polymeric isocyanates also react slowly and exothermically on contact with water $(4,5)$.

Hazardous Decomposition Products: Toxic fumes of carbon monoxide, carbon dioxide, nitrogen oxides and hydrogen cyanides may be produced upon thermal decomposition of isocyanates $(17,18)$. Thermal decomposition at temperatures below ignition have been shown to produce toxic isocyanate vapors as well as MDA (16).

\section{FrEON $^{\circledR} 11$}

Chemical Name (19):

Trichlorofluoromethane

\section{Molecular Formula: \\ $\mathrm{CCl}_{3} \mathrm{~F}$}

\section{CAS Number:}

$75-69-4$

Chemical and Physical Properties (20):

Melting Point: $-168^{\circ} \mathrm{F}\left(-111^{\circ} \mathrm{C}\right)$

Boiling point: $75^{\circ} \mathrm{F}\left(24^{\circ} \mathrm{C}\right)$

Flash Point: None TOC

Appearance: Colorless liquid 
Odor: Slight ethereal odor

Solubility in Water: $0.1 \%$ by wt. @ $77^{\circ} \mathrm{F}$

Exposure limits (6):

OSHA PEL: $\quad$ CEIL $=5620 \mathrm{mg} / \mathrm{m}^{3}(1000 \mathrm{ppm})$

NIOSH: $\quad \mathrm{CEIL}=5600 \mathrm{mg} / \mathrm{m}^{3}(1000 \mathrm{ppm})$

ACGIH TLV: CEIL $=5600 \mathrm{mg} / \mathrm{m}^{3}(1000 \mathrm{ppm})$

Toxicology : Trichlorofluoromethane (FREON $\left.{ }^{\circledR} 11\right)$ is a colorless gas or liquid used as a refrigerant and/or propellant (19). It is toxic following inhalation of the vapors or prolonged skin exposure. In screening tests with experimental animals, exposure to approximately $5,000 \mathrm{ppm}(\mathrm{v} / \mathrm{v})$ followed by a large intravenous epinephrine challenge has induced serious cardiac irregularities $(2,3)$.

Rat - Oral LD50 $=>3725 \mathrm{mg} / \mathrm{kg}$ (19).

Rat - Inhalation LC50 $=26,200 \mathrm{ppm} / 4 \mathrm{hr}$. (19).

Acute Exposure: Vapor is heavier than air and can cause suffocation by reducing oxygen available for breathing. Concentrations of $10,000 \mathrm{ppm}$ are considered immediately dangerous to life or health (2).

Chronic Exposure: Repeated or prolonged dermal exposure to FREON ${ }^{\circledR} 11$ may cause dermatitis with irritation, reddening, drying and cracking of the skin (21).

Eye Exposure: Chronic exposure to FREON ${ }^{\circledR} 11$ to the eyes of rabbits resulted in no observable damage other than a mild hyperemia and slight inflammation of the eyelid $(11,22)$. Rapid evaporation of the liquid gas may cause frostbite, pain, and blurred vision.

Inhalation Exposure: FREON $^{{ }}-11$ is considered a simple asphyxiant / narcotic (2). Exposure to high concentrations of the gas may cause pulmonary edema, bronchial constriction, lung irritation and central nervous system depression. The symptoms of asphyxia depend on the rapidity with which the oxygen deficiency develops and how long it continues. In sudden acute asphyxia, unconsciousness may be immediate. With slow development there may be rapid respiration and pulse, dizziness, reduced awareness, tightness in the head, tingling sensations, incoordination, faulty judgment, emotional instability and rapid fatigue. As the asphyxia progresses, nausea, vomiting, collapse, unconsciousness, convulsions, coma and death are possible (23). In addition acute exposures to high concentrations of chlorofluorocarbons has caused sudden death by cardiac arrest, probably due to sensitization of the myocardium to endogenous catecholamines resulting in ventricular fibrillation $(23,24)$.

Oral Exposure: Ingestion of the gas is unlikely, however, ingestion of the liquid can produce frostbite, damage to the lips, mouth and mucous membranes $(2,25)$. 
Dermal Exposure: FREON ${ }^{\circledR} 11$ is not a corrosive or irritant material, however, repeated or prolonged contact with the liquid can cause defatting of the skin resulting in dermatitis. Individuals with pre-existing skin disorders may be more susceptible to the effect of this agent (21).

Carcinogenicity: Exposure of trichlorofluoromethane to sprague-dawley rats did not result in carcinogenic effects (26). FREON ${ }^{\otimes} 11$ is not listed as a carcinogen by NTP, IARC or ACGIH, nor is it regulated as a carcinogen by OSHA (6).

Reproductive Effects: There have been no reproductive effects noted with this compound $(2,3)$.

Incompatibility: FREON ${ }^{\circledR} 11$ is incompatible with alkali or alkaline earth metals powdered $\mathrm{Al}, \mathrm{Zn}$, and $\mathrm{Be}(19)$.

Hazardous Decomposition Products: FREON ${ }^{\circledR} 11$ A can be decomposed by high temperatures (open flames, glowing surfaces etc.) forming hydrochloric and hydrofluoric acids and possible carbonyl halides (19).

\section{Pluracol $^{\circledR}$ PeP 450:}

Chemical Name (27):

Propylene oxide adduct of penetaerythritol, 560 hydroxyl number (28.1\%).

\section{Molecular Formula:}

Polyether polyol

\section{CAS Number:}

9051-49-4

Chemical and Physical Properties (27, 28):

Melting Point: NA

Boiling point: Not distillable

Flash Point: $365^{\circ} \mathrm{F}, \mathrm{COC}$

Appearance: Water white, viscous liquid

Odor: No odor

Solubility in Water: Soluble

Exposure limits (6):

No occupational exposure limits have been established by ACGIH, OSHA, or NIOSH. 
Toxicology : The toxic effects of this material have not been determined. Pluracol 434 may cause slight skin or eye irritation upun contact. Acute Toxicity studies in the rat suggest that this material is essentially non-toxic with a Rat-oral $L D 50=20.8$ $\mathrm{g} / \mathrm{kg}(27)$.

The following information on potential health effects for Pluracol 434 is based the information available for this material and on the toxicological information available for similar materials such as polypropylene glycol. In general, polypropylene glycols pose essentially no toxicity hazard following dermal or inhalation exposure (29).

Acute Exposure: Acute ingestion is not expected to result in toxicity (30). Contact with the eyes and skin may result in irritation. There are no other known acute effects associated with exposure to Pluracol $^{\circledR} 450(31,32)$.

Chronic Exposure: There are no known effects associated with chronic exposure to polypropylene glycols $(2,3,31)$.

Eye Exposure: Direct of the liquid with the eyes may result slight transient pain and conjunctiva irritation but no corneal damage $(11,27)$.

Inhalation Exposure: Due to its low vapor pressure, this material is not considered an inhalation hazard at normal temperatures. Monkeys and rats exposed to atmospheres saturated with propylene glycol vapor experienced no adverse effects after periods of $12-18$ months. Furthermore, humans exposed to saturated and supersaturated atmospheres for prolonged periods did not exhibit serious toxicological effects $(31,32,33)$.

Oral Exposure: Oral exposure is not considered a major route of exposure in the workplace. However, glycols are generally well absorbed by the digestive tract resulting in moderate toxicity following chronic ingestion (30).

Dermal Exposure: The primary route of exposure expected with this material is dermal. Tests on rabbits have indicated that polypropylene glycols are not significantly irritating to the skin even when exposures are prolonged and repeated (31).

Carcinogenicity: None of the glycols or their derivatives have found to be mutagenic, carcinogenic, or teratogenic. Pluraco ${ }^{\circledR} 450$ has not been listed as a carcinogen by NTP, IARC, or ACGIH nor is it regulated as carcinogens by OSHA (6).

Reproductive Effects: There are no known reproductive effects associated with this material $(2,3)$. Although some glycol ethers such as ethylene glycol monomethyl ether and ethylene glycol monoethyl ether have been associated with 
reproductive toxicity, propylene glycols are not considered reproductive toxins $(34,35)$.

Incompatibility: There are no known incompatible materials that affect the health hazards of this material. However, the MSDS for this material suggests avoidance of exposures to moisture and temperatures above $200^{\circ} \mathrm{F}(27,28)$.

Hazardous Decomposition Products: No hazardous decomposition products have been identified. This material does not undergo hazardous polymerization $(27,28)$.

\section{DABCO ${ }^{\oplus}$ - 33LV}

Chemical Name (36):

Triethylenediamine

Molecular Formula:

$\mathrm{C}_{6} \mathrm{H}_{12} \mathrm{~N}_{2}$

\section{CAS Number:}

280-57-9

Chemical and Physical Properties (37):

Melting Point: $158-160^{\circ} \mathrm{C}$ (sublimes readily at room temp.) .

Boiling point: $345^{\circ} \mathrm{F}\left(174^{\circ} \mathrm{C}\right)$

Flash Point: $>122^{\circ} \mathrm{F},\left(>50^{\circ} \mathrm{C}\right) \mathrm{COC}$

Appearance: Moist, white, crystalline powder

Odor: Sharp ammonia-like odor

Solubility in Water: Soluble at $45 \mathrm{~g} / 100 \mathrm{~g}$ at $25^{\circ} \mathrm{C}$

Exposure limits (6):

No occupational exposure limits for this material have been established by ACGIH, OSHA, or NIOSH.

Toxicology : Triethylenediamine is considered harmful if swallowed, inhaled, or absorbed through the skin. This material is extremely destructive to the tissues of the mucous membranes and upper respiratory tract, eyes and skin (38).

Oral-rat LD50 = $1700 \mathrm{mg} / \mathrm{kg}$ (39)

Oral-rabbit LD50 $=1100 \mathrm{mg} / \mathrm{kg}$ (39)

Oral-guinea pig LD50 $=2250 \mathrm{mg} / \mathrm{k}(39) \mathrm{g}$ 
Acute Exposure: Triethylenediamine is an extremely corrosive material and acute exposure results in severe irritation and burning of the upper respiratory tract. Pulmonary edema has also been known to develop following an acute exposure (2).

Chronic Exposure: Repeated or prolonged exposure to this material may cause inflammatory and ulcerative changes in the mouth as well as the bronchial and gastrointestinal tracts (2).

Eye Exposure: Direct contact of the eyes with triethylenediamine may result in pain and burning of the eyes. Corneal edema and destruction of the epithelium have been known to occur in wurkers exposed to the vapor (11).

Inhalation Exposure: Inhalation may be fatal as a result of spasm, inflammation and edema of the larynx and bronchi, chemical pneumonitis and pulmonary edema Symptoms of exposure may include burning sensation, coughing, wheezing, laryngitis, shortness of breath, headache, nausea, and vomiting $(36,37)$.

Oral Exposure: Ingestion of triethylenediamine results in symptoms such as seen with alkaline corrosives. Acute exposure may cause immediate burns and corrosion of the mucous membranes accompanied by profuse salivation and difficulty or inability to swallow or speak. In severe CASes esophageal or gastric perforation may also occur $(36,37)$.

Dermal Exposure: Dermal exposure to this material results in severe pain, burns and possibly brownish stains. Repeated or prolonged contact may result in sensitization $(36,37)$.

Carcinogenicity: Triethylenediamine is not listed as a carcinogen by NTP, IARC or ACGIH, nor is it regulated as a carcinogen by OSHA (6).

Reproductive Effects: There is no known reproductive effects associated with exposure to this material $(2,3)$.

Incompatibility: Triethylenediamine is incompatible with strong oxidizing agents and strong acids $(36,37)$.

Hazardous Decomposition Products: Thermal decomposition of triethylenediamine results in the production of carbon dioxide, carbon monoxide and nitrogen oxides $(36,37)$ 


\section{$\mathrm{DABCO}^{\oplus} \mathrm{DC}^{\circ} 197$}

Chemical Name (40):

Dimethylpolysiloxane (polyoxyethyleneglycol) silicone copolymer

Molecular Formula:

NA

CAS Number:

68037-63-8

Chemical and Physical Properties (41):

Melting Point: NA

Boiling point: $250^{\circ} \mathrm{F}\left(121^{\circ} \mathrm{C}\right)$

Flash Point: $198^{\circ} \mathrm{F}, \mathrm{COC}$

Appearance: Clear Liquid

Odor: None

Solubility in Water: $<1 \%$

Log Octanol/water partition coefficient: No data

Exposure limits (6):

No occupational exposure limits have been established by ACGIH, OSHA, or NIOSH.

Toxicology : Dimethylpolysiloxane (Polyoxyethyleneglycol) Silicone Copolymer is considered a mild skin and eye irritant. It is used as a surfactant in the Rigid Foam system to promote gas nucleation and provide bubble stability. Silicone oils are characterized by their chemical inertness, low temperature coefficient of viscosity, wide liquid range and low freezing point. Silicone oils have a low order of toxicity as a group, but repeated skin contact to dimethylpolysiloxanes can result in mild skin and eye irritation (41).

Acute Exposure: Acute inhalation or dermal exposure to dimethyl polysiloxanes causes mild irritation and discomfort (42). Acute over exposure to the products of combustion may result in irritation of the respiratory tract (41).

Chronic Exposure: Repeated or prolonged exposure to the skin may cause primary skin irritation and dermatitis. This product has been shown to enhance allergic conditions such as skin allergies $(40,41)$. There is no indication that silicones produce the chronic health effects seen with chronic exposure to silica dust (43).

Eye Exposure: Direct contact with the eyes may cause temporary discomfort with mild redness and dryness similar to windburn $(2,11)$. 
Inhalation Exposure: Although chronic inhalation exposure to respirable silica dust results in a chronic fibrosing lung disease (Silicosis), there is no evidence of adverse health effects resulting from inhalation exposure to silicon oxide polymers (silicones) such as the silicone copolymer in DC $197(43,44,45)$.

Oral Exposure: Silicones in general, have a very low oral toxicity. There is no evidence of adverse health effects due to ingestion of polydimethylsiloxane other than gastrointestinal irritation (42).

Dermal Exposure: A single relatively short exposure (5-10 minutes) causes no known adverse effects. However, several repeated prolonged exposures (24 to 48 hours) may irritate the skin resulting in dermatitis $(41,42)$.

Carcinogenicity: Studies of women with silicone implants have not demonstrated a causal relationship between silicone implants, cancer or autoimmune disease (43, 44, 45). DC 197 is not listed as a carcinogen by NTP, IARC, or ACGIH, nor is it regulated as a carcinogen by $\mathrm{OSHA}(6)$.

Reproductive Effects: Studies on the reproductive and teratogenic effects of polydimethylsiloxanes have been inconclusive $(46,47)$. However epidemiological studies on women with silicone implants have not demonstrated an increase in reproductive or teratogenic effects (44).

Incompatibility: This material is not compatible with strong oxidizing compounds (41).

Hazardous Decomposition Products: Thermal decomposition of this material may produce toxic fumes of Silicon Dioxide, Carbon Dioxide, and traces of incompletely burned carbon products $(40,41)$.

\section{FREON @ 12}

Chemical Name (48):

Dichlorodifluoromethane

\section{Molecular Formula:}

$\mathrm{Cl} 2-\mathrm{C}-\mathrm{F} 2$

\section{CAS Number:}

$75-71-8$ 


\section{Chemical and Physical Properties (48):}

Melting Point: $-252^{\circ} \mathrm{F}\left(-158^{\circ} \mathrm{C}\right)$

Boiling point: $-22^{\circ} \mathrm{F}\left(-30^{\circ} \mathrm{C}\right)$

Flash Point: NA

Appearance: Colorless Gas

Odor: Faint ether-like odor

Solubility in Water: $0.028 \% @ 25^{\circ} \mathrm{C}$

Log Octanol/water partition coefficient: NA

Exposure limits (6):

OSHA PEL: TWA $-1000 \mathrm{ppm}\left(4950 \mathrm{mg} / \mathrm{m}^{3}\right)$

NIOSH TWA $-1000 \mathrm{ppm}\left(4950 \mathrm{mg} / \mathrm{m}^{3}\right)$

ACGIH TLV: TWA - 1000 ppm (4950 mg/m $\left.{ }^{3}\right)$

Toxicology: Dichlorodifluoromethane (FREON $\left.{ }^{\circledR}-12\right)$ is a colorless gas with a faint odor commonly used as a refrigerant and/or propellant (48). Exposure may effect the central nervous system and respiration. Sudden death has been reported following intentional inhalation of freons. It is believed that the cause of death is due to ventricular fibrillation as a result of direct sensitization of the myocardium to endogenous catecholamines $(48,49)$.

Acute Exposure: Acute exposure to FREON ${ }^{\circledR}-12$ may cause drunkenness, suffocation, blisters, frostbite, blurred vision, nausea, vomiting, twitching, weakness, numbness, convulsions, blood disorders, heart failure, collapse, unconsciousness and coma (23)

Chronic Exposure: Repeated or prolonged exposure to FREON ${ }^{\circledR}-12$ may result in effects similar to a large acute exposure (24).

Eye Exposure: Ordinary occupational and domestic exposure to the fluorocarbons is not expected to cause ocular irritation. However, 200,000 ppm for 30 minutes has been reported to cause irritation (25). Rapid evaporation of the liquefied gas may cause frostbite, redness, pain, and blurred vision (11).

Inhalation Exposure: FREON $^{\circledR}-12$ is considered a simple asphyxiant / narcotic Exposure to high concentrations of the gas may cause pulmonary edema, bronchial constriction, lung irritation and central nervous system depression. The symptoms of asphyxia depend on the rapidity with which the oxygen deficiency develops and how long it continues. In sudden acute asphyxia, unconsciousness may be immediate. With slow development there may be rapid respiration and pulse, dizziness, reduced awareness, tightness in the head, tingling sensations, incoordination, faulty judgment, emotional instability and rapid fatigue. As the asphyxia progresses, nausea, vomiting, collapse, unconsciousness, convulsions, coma and death are possible (23). In addition acute exposures to high 
concentrations of chlorofluorocarbons has caused sudden death by cardiac arrest, probably due to sensitization of the myocardium to endogenous catecholamines resulting in ventricular fibrillation $(23,24)$.

Oral Exposure: Ingestion of the gas is unlikely, however, ingestion of the liquid can produce frostbite, damage to the lips, mouth and mucous membranes $(2,25)$.

Dermal Exposure: No adverse effects have been reported following dermal exposure to the gas. However, rapid evaporation of the liquefied material may cause frostbite with redness, tingling, pain or numbness $(3,48)$.

Carcinogenicity: FREON ${ }^{\circledR}-12$ is not listed as a carcinogen by NTP, IRAC, or ACGIH, nor is it regulated as a carcinogen by $\operatorname{OSHA}(2,3)$.

Reproductive Effects: There have been no reproductive effects noted with this compound $(2,3)$.

Incompatibility: Under certain conditions, fluorocarbons can form exothermic reactions with aluminum, calcium, magnesium, metals, potassium, sodium, and zinc (48).

Hazardous Decomposition Products: Thermal decomposition products may include toxic fumes of phosgene and carbonyl halides and toxic and corrosive fumes of chlorides and fluorides. Hazardous polymerization has not been reported to occur under normal temperatures and pressures (48). 


\section{References}

1. Rand, P.R., Personal communication. (1993).

2. National Library of Medicine Toxicology Data Network, Hazardous Substance Data Bank (HSDB). TOXNET, (1993).

3. National Library of Medicine Toxicology Data Network, Registry of Toxic Effects of Chemical Substances (RTECS). TOXNET, (1993).

4. DOW Corning Corporation. PAPI -580. U.S. Department of Labor Occupational Safety and Health Administration, Material Safety Data Sheet, (1987).

5. Occupational Health Services PAPI - 580. U.S. Department of Labor Occupational Safety and Health Administration, Material Safety Data Sheet, (1991).

6. American Conference of Governmental Industrial Hygienists, Guide to Occupational Exposure Values-1992. ISBN:0-936712-98-8, (1992).

7. Amdur, M.O., Doull, J., and Klaassen, C.D., CASarett and Doull's Toxicology, Fourth Edition., Mc Graw-Hill, (1991).

8. Woolrich, P.F., Toxicology, Industrial Hygiene and Medical Control of TDI, MDI, and PMPPI. AIHA J., 43 (2): 89-97, (1982).

9. Clayton, G.D., and Clayton, F.E., Polyurethanes. In Patty's Industrial Hygiene and Toxicology, A Wiley-Interscience Publication 3rd edition, Vol. 2C, p. 4447-4464 (1991).

10. Karol, M.H., Dixon, D., Brady, and Alarie, Y., Immunologic Sensitization and Pulmonary Hypersensitivity by Repeated Inhalation of Aromatic Isocyanates. Toxicol. Appl. Pharmacol., 58: 260-270, (1980).

11. Grant, W.M., Toxicology of the Eye. Third Edition, Charles C. Thomas (1986).

12. Karol, M.H., Concentration-dependent Immunologic Response to Toluene Diisocyanate (TDI) Following Inhalation Exposure. Toxicol. Appl. Pharmacol., 68 229-241, (1983).

13. The Upjohn Chemical Company, Urethanes, Engineering, Medical Control and Toxicological Considerations, Technical Bulletin-105, (1968).

14. Brugsch, H.G., and Elkins, H.B., Toluene Di-isocyanate (TDI) Toxicity. New England J. of Med. 268: 353-357, (1963). 
Toxicology Evaluation and Hazard Review

Rigid Foam

15. Karol, M.H., Hauth, B.A., Riley, E.J., and Magreni, C.M., Dermal Contact with Toluene Di-isocyanate (TDI) Produces Respiratoru Tract Hypersensitivity in Guinea Pigs. Toxicol. Appl. Pharmacol., 58: 221-230, (1981).

16. Larsen, F., On the Generation of Methylenedianiline from the Thermal Degradation of MDI Based Polyurethane Foams. Allied Signal Aerospace, Kansas City Division, Polymers Technical Exchange Conference Allied-Signal Corporate Headquarters Morristown, New Jersey, (1992).

17. Hileman, F.D., Voorheers, K.J., Wojcik, L.H., et. al. Pyrolysis of a Flexible Urethane Foam. J. Polymer Sci. 13: 571-580, (1975).

18. Foti, S., Maravigna, P., Montando, G., Mechanisms of Thermal Decomposition in Totally Aromatic Polyurethanes, J. Poly-Sci., 19: 1679- , (1981).

19. Occupational Health Services, Trichlorofluoromethane, U.S. Department of Labor Occupational Safety and Health Administration, Material Safety Data Sheet, (1980).

20. Windholz, M., Budavari, S., Blumetti, R.F., and Otterbein, E.S., The Merck Index. 10th edition, Merck \& Co., Inc (1983).

21. Goodman, A.G., and Gilman, A.G., Goodman and Gilman's: The Pharmacological Basis of Terapeutics. 5th edition, p. 910, (1975).

22. World Health Organization, Fully Halogenated Chlorofluorocarbons. Environmental Health Critera 113: p. 93, (1990).

23. Clark, D.G., and Tinston, D.J., Acute Inhalation Toxicity of Some Halogenated and Non-halogenated Hydrocarbons. Human Toxicology 1: 239-247, (1982)

24. Poika, M. J., Heikkila, J., and Saarinen, L., Cardiac Arrhythmias During Occupational Exposure to Fluorinated Hydrocarbons. British Journal of Industrial Medicine, 47: 138-140, (1990).

25. Parmeggiani, L., Fluorocarbons, In Encyclopedia of Occupational Health and Safety, p. $896-899$ (1983).

26. Maltoni, C., Lefemine, G., Tovoli, D., and Perino, G., Long-Term Carcinogenicity Bioassays on Three Chlorofluorocarbons: Trichlorofluoromethane FCII, Dichlorodifluoromethane FC12, and Chlorodifluoromethane FC22 Administered by Inhalation to Sprague-Dawley Rats and Swiss Mice. Annals of the New York Academy of Sciences, 534: 261-282, (1988). 
Toxicology Evaluation and Hazard Review

Rigid Foam

27. BASF Wyandotte Corporation, Pluracol Polyol 450, U.S. Department of Labor Occupational Safety and Health Administration, Material Safety Data Sheet, (1980).

28. Occupational Health Services, Pluracol Polyol 450, U.S. Department of Labor Occupational Safety and Health Administration, Material Safety Data Sheet, (1980).

29. Parmeggiani, L., Glycols and Derivatives, In Encyclopedia of Occupational Health and Safety, p. 973-976, (1983).

30. Gosselin, R.E., Smith, R.P., and Hodge, H.C., Polypropylene glycols. In Clinical Toxicology of Commercial Products, 5th edition, p. II-179, (1984).

31. Clayton, G.D., and Clayton, F.E., Patty's Industrial Hygiene and Toxicology. Vol. 2A, 2B, and 2C, 3rd edition, A Wiley-Interscience Publication, (1991).

32. Amdur, M.O., Doull, J., and Klaassen, C.D., CASarett and Doull's Toxicology. Fourth edition, McGraw Hill, (1991).

33. Landry, T.D., Gushow, T.S., and Yano, B.L., Propylene Glycol Monomethylether: a 13-week Vapor Inhalation Toxicity Study in Rats and Rabbits. Fund. Appl. Toxicol., 3: $627-630,(1983)$.

34. Hanley, T.R., Young, J.T., John, J.A., and Roa, D.L., Ethylene Glycol Monomethyl Ether (EGME) and Propylene Glycol Monomethyl Ether (PGME): Inhalation Fertility and Teratogenicity Studies in Rats, Mice and Rabbits. Environ. Health Prospect., 57: 7-12, (1984).

35. Schenker, M., Epidemiologic Study of Reproductive and Other Health Effects Among Workers Employed in the Manufacture of Semiconductors. Division of Occupational / Environmental Medicine and Epidemiology Department of Internal Medicine, (1992).

36. Dow Corning, $D A B C O 33 \mathrm{LV}$, U.S. Department of Labor Occupational Safety and Health Administration, Material Safety Data Sheet, (1991).

37. Occupational Health Services, Triethylenediamine U.S. Department of Labor Occupational Safety and Health Administration, Material Safety Data Sheet, (1993).

38. Brieger, H., and Hodes, W.A., The Toxic Effects of Exposure to Vapors of Aliphatic Amines. A.M.A. Archives of Industrial Hygiene and Occupational Medicine, 3: 287291 (1951).

39. Egorova, NA., Prognosis of Toxicity Parameters of Various Groups of Chemical Compounds on the Basis of Structure-Action Relationships. Gig. Sanit. 45(5): 67-70 (1980). 
Toxicology Evaluation and Hazard Review

Rigid Foam

40. Air products and Chemicals, $D A B C O \circledast 197$ Surfactant, U.S. Department of Labor Occupational Safety and Health Administration, Material Safety Data Sheet, (1985).

41. Occupational Health Services, DABCO DC197. U.S. Department of Labor Occupational Safety and Health Administration, Material Safety Data Sheet, (1993).

42. Carpenter, C.P., Weil, C.S., and Smyth, H.F., Range-Finding Toxicity Data. Toxicol. Appl. Pharmacol., 28: 313-319 (1974).

43. International Agency for Research on Cancer, Silica and Some Silicates. IARC Monographs on the Evaluation of the Carcinogenic Risk of Chemicals To Humans, 42: 39-144, (1987).

44. Nemecek, J.A., and Young, V.L., How Safe are Silicone Breast Implants?, Southern Med. J., 86(8): 933-944, (1993).

45. Hidalgo, D.A., Are Breast Prostheses Safe for Use in Breast Reconstruction? Yes: Important Advances in Oncology, 179-188, (1993).

46. Kennedy, G.L., Keplinger, MiE., Calandra, J.C., Reproductive, Teratologic, and Mutagenic Studies with Some Polydimethylsilonanes. J. Toxicol. Environ. Health, 1(6): 909-920, (1976).

47. Bates, H.R., Filler, H.R., Kimmel, C., Developmental Toxicity Study of Polydimethylsiloxane Injection in the Rat. Teratology, 31: 50-58, (1985).

48. Occupational Health Services Inc., Dichlorodifluoromethane. Material Safety Data Sheet, (1992).

49. Azar, A., Reinhardt, C.F., Maxfield, M.E., Smith, P.E., and Mullin, L.S., Experimental Human Exposures to Fluorocarbon 12 (Dichlorodifluoromethane) Amer. Indust. Hygiene Assoc. J., April: 207-216, (1972). 
Toxicology Evaluation and Hazard Review

Rigid Foam

\section{Conclusions}

The results of our evaluation indicate that the two formulations of Rigid Foam are of comparable toxicity. Fully deployed Rigid Foam is a crosslinked resin used to encapsulate an object or prevent access to an area. Under normal conditions of use and/or deployment, Rigid Foam is not expected to produce a significant health hazard. However, Rigid Foam is produced by the reaction of a toxic isocyanate component with a polyol to form the final foam product. Although the volatility of the final foam product is low enough that hazardous isocyanate vapor concentrations are unlikely during normal deployment, the possibility does exist for thermal decomposition at temperatures below ignition resulting in the generation of toxic isocyanate vapors or other toxic vapors. In addition, a partial deployment in which only the toxic isocyanate component " $\mathrm{A}$ " is released would pose a significant health hazard Furthermore, the heat generated by the polymerization of the foam could potentially cause burns to an individual in direct contact with the foaming process.

Studies indicate that the major thermal decomposition products of polyurethanes and polyisocyanates are carbon dioxide, carbon monoxide, hydrocarbons, and various polymer fragments. Nitrogen oxides and hydrogen cyanide are also formed, but in lesser amounts. These decomposition products are not significantly different than that of products formed from commonly accepted organic materials such as cotton, wool, polyester and nylon. However, thermal decomposition of the foam in the absence of ignition, can result in the release of toxic isocyanate gases or methylenedianiline, a known carcinogen.

The components of Rigid Foam also present a hazardous situation in the event of a partial deployment of the foam in which only the " $\mathrm{A}$ " component is released The "A" component of the Rigid Foam process consists of toxic polymeric isocyanates which are severe irritants to the tissues of the mucous membranes and upper respiratory tract. Exposure to isocyanates can cause a pulmonary hypersensitivity that can result in a severe isocyanateinduced asthmatic condition. Release of the " $B$ " component in the absence of the " $A$ " component is not expected to result in a hazardous situation.

In addition, FREON-12 is a simple asphyxiant and is released during the foaming process. While deployment under normal conditions in a well ventilated area is not expected to pose an asphyxiation hazard due to oxygen depletion, deployment in a confined space could present a hazard. This hazardous condition is only significant if an individual is in the area during the foaming process and would not be expected under normal deployment of Rigid Foam. 


\section{DISTRIBUTION:}

1 8523-2 Central Technical Files, MS 9018

57141 Technical Library, MS 0899

17151 Technical Publications, MS 0619

10 7613-2 Document Processing for DOE/OSTI, MS 0100

1 DOE/TSD/TSB R.H. Richey

$10323 \quad$ L.M. Weston, MS 0829

$1 \quad 1811 \quad$ P.B. Rand, MS 0368

$1 \quad 1832$ L.M. Maestas, MS 0340

$1 \quad 6411 \quad$ T.M. Hake, MS 7144

$17711 \quad$ M.M. Archuleta, MS 0651

$17711 \quad$ C.J. Pigg, MS 0651

17712 W.E. Stocum, MS 0651

19603 E.R. Hoover, MS 0767

19611 T. D. Goolsby, MS0783

$19611 \quad$ C.J. Greenholt, MS 0783

19611 D.J. Pedrotty, MS 0783

$19611 \quad$ S.H. Scott, MS 0783

$19611 \quad$ M.R. Kodlick, MS 0783

19612 H.J. Abeyta, MS 0790

$19612 \quad$ R.C. Cranfill, MS 0790

19612 G.W. Crowder, MS 0790

19613 J.J. Roesch, MS 0790

19613 J.K. Deuel, MS 0790

19614 W.F. Hartman, MS 0763 

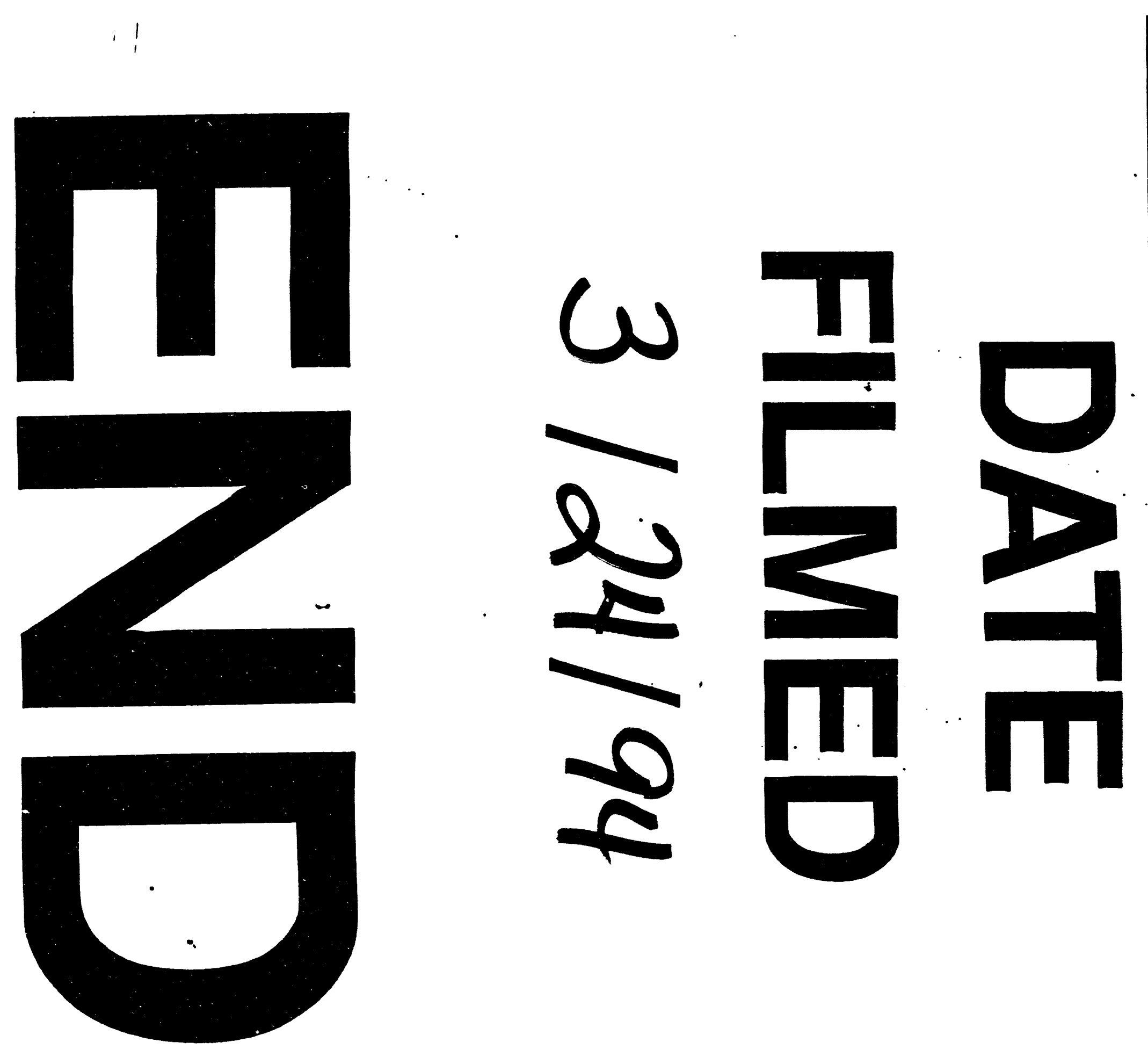
